CHAPTER 7:

\title{
Estonia: Civic and Citizenship Education in Turbulent Times
}

\author{
Anu Toots and Mare Oja
}

\begin{abstract}
This chapter addresses Estonia's participation in IEA's Civic Education Study (CIVED), International Civic and Citizenship Education Study (ICCS) 2009, and ICCS 2016. Participation in these IEA civic studies contributed to educational discourse in Estonia by transforming the state-centered subject into broader society-centered and age-relevant concepts of citizenship. Study findings affected curriculum and textbooks' content and external testing policy. Uniquely, in Estonia IEA civic studies had a breakthrough effect outside formal education by contributing to lowering the voting age to 16 in municipal elections. Finally, the chapter addresses the challenge and national experience of integrating Russian-speaking youth into society through civic and citizenship education.
\end{abstract}

\section{General Background Information on the Period 1999-2016}

Estonia has participated in all International Association for the Evaluation of Education Achievement (IEA) civic and citizenship education studies since the mid-1990s. At that time the majority of policymakers began to realize the importance of comparing national educational outcomes internationally. This broad consensus facilitated the country's participation in IEA's Civic Education Study (CIVED), International Civic and Citizenship Education Study (ICCS) 2009, and ICCS 2016. Estonia became an IEA member in 2003. Recently there is some survey fatigue, and every new study provokes intensive discussions about participation. Despite this, the decision to take part in ICCS 2022 has been confirmed.

The participation of Estonia in international civic and citizenship education (CCE) surveys is part of a broader picture of societal transformation. After the collapse of the Soviet Union in 1991, Estonia restored its independence and launched rather radical reforms to transition from a totalitarian regime to a liberal democracy. In foreign affairs this meant joining all major international organizations-United Nations (1991), Council of Europe (1993), North Atlantic Treaty Organization (NATO) (2004), Organisation for Economic Co-operation and Development (OECD) (2010), and the European Union (EU) (2004). Domestically, two areas have special importance for CCE: first, democratization of formal education and second, integration of Russian speaking schools and students. During Soviet times about 15\% of lower secondary schools had Russian as the language of instruction, decreasing to 7\% by 2016 (Statistics Estonia 2020).

Although all schools in Estonia follow the national curriculum and use textbooks approved by the Ministry of Education, curriculum and teaching practices in Estonian-speaking and Russianspeaking schools differ. This made modernization of national curriculum even more urgent. In 25 years, there have been several curriculum reforms that changed the status and content of social studies substantially. The trend throughout the entire period was to move away from lawcentered teaching of state and government topics to the concept of democratic citizenship, which encompasses democratic attitudes and participatory patterns as well as knowledge. Assessment of students' cognitive capacities has a long tradition in Estonian education. In CCE learning outcomes are assessed via national tests at the end of lower and upper secondary school. Due

Anu Toots, Tallinn University, Tallinn, Estonia

email: anuto@tlu.ee

Mare Oja, Tallinn University, Tallinn, Estonia

email:mareoja@tlu.ee

(C) IEA International Association for the Evaluation of Educational Achievement 2021

B. Malak-Minkiewicz and J. Torney-Purta (eds.), Influences of the IEA Civic and Citizenship Education Studies, https://doi.org/10.1007/978-3-030-71102-3_7 
to the totalitarian past much less was known about youth social and political attitudes and their political participation. IEA civic and citizenship studies have become the main source of this information (Torney-Purta et al. 2001; Amadeo et al. 2002; Schulz et al. 2010; Schulz et al. 2018). CIVED and ICCS also stimulated interest among researchers in Estonia, which resulted in further comparative studies on CCE in Eastern and Western Europe (Krzywosz-Rynkiewicz et al. 2018).

Some EU funded research projects, such as Memory, Youth, Political Legacy \& Civic Engagement (MYPLACE), 2011-15, and Constructing AcTive, CitizensHip with European Youth (CATCHEyoU), 2015-18, have also provided reliable insights about democratic attitudes and political participation among young people. MYPLACE studied linkages between the historical past and current civic attitudes and engagement of young people in various regions. The findings revealed that youth civic engagement is affected primarily by a student's political interest, parents' education, and socioeconomic status, and less by historic memories. MYPLACE confirmed the weak propensity of young people to participate through traditional institutional forms and their greater participation in non-conventional activities (Pilkington and Pollock 2015). CATCH-EyoU focused on young people's trust in EU institutions and their active engagement in Europe (Motti-Stefanidi and Cicognani 2018). Findings on youth media use indicated that trust in alternative media is related to negative attitudes towards the EU (Macek et al. 2018). However, both MYPLACE and CATCH-EyoU differ methodologically from the IEA civic studies by encompassing a larger age range of respondents and using multiple methods; these studies did not measure civic knowledge.

This chapter examines the role of IEA CCE studies in the modernization of social studies in Estonia and their broader impact on youth policy. The chapter authors have been active participants in these multifaceted developments. Anu Toots, a professor of Tallinn University served as the national research coordinator for CIVED, ICCS 2009, and 2016; she has been one of the key advisors in the lowering the voting age and an expert on curriculum development task forces. Mare Oja worked 1993-2011 in the Ministry of Education, the National Board of Education, and the National Qualification and Examination Centre as an expert in social sciences. She has been engaged in national curriculum reform in the area of history and social studies. She teaches in initial teacher training programs at Tallinn University.

Besides the authors' expert knowledge, the chapter relies on national legal acts and policy strategies, reports on national testing in CCE, higher education teacher training regulations, and school related mass media. Personal communication with experts and civil servants involved in curriculum development is also used.

\section{Development of National Curriculum Policy}

Democratization of the Estonian school system began at the end of the 1980s when liberalization reforms in the Soviet Union made open public debates possible. The Soviet-style civic education was replaced by the history of philosophy, regarded as a less politicized subject. In 1992-1993 when civic education programs were composed, they were not compulsory and were not accompanied by modern textbooks or study materials. Thus, the implementation of the CCE subject in classrooms depended on the professionalism and attitudes of the teachers. A turning point came in 1996, when the first national curriculum of the post-totalitarian period was enacted as a binding government decree. This document laid down the institutional and ideational foundations of the national educational policy that are still effective. All schools regardless of status and language of instruction had to follow the national curriculum. The national curriculum established a two-layered structure: a general part, which defined basic values of education and the grade structure of the school, and a second part, which included study programs for each compulsory subject. Despite huge changes in ideational approach, Estonia kept the traditional subject-based structures of teaching. This holds also for CCE defined as a compulsory separate subject in lower and upper secondary school. 


\section{Main Reforms in the Area of Civic and Citizenship Education Curriculum}

The first national curriculum (1996) listed a broad range of topics to be taught in CCElogic, constitution, principles of democracy, social structure, and economics. This reflects the educational policy trade-off in a transition period that tried to combine philosophy, law, economics, and civics in order to accommodate different visions of CCE. Precise guidelines on teaching practices were not provided. That left the implementation of curriculum largely dependent on teachers. Some of them liked the freedom to design the pedagogical approaches and content of classes while others expressed confusion and resistance to this novel situation. The first textbook based on the curriculum 1996 was published in 1997 to help teachers cope with the lack of teaching materials.

The revised curriculum (2002) attempted to advance the cross-curricular approach to CCE, emphasizing the importance of the democratic school. In reality, the main responsibility in teaching democracy remained with the subject teachers and the CCE classes. An intention to put more stress on imparting skills and participatory attitudes was stated, though no substantial change in this aspect has been achieved. Efforts to improve this participatory dimension were undermined by the low knowledge achievement of Estonian students in CIVED. Given the national educational tradition, poor cognitive competences were regarded as a bigger problem than the modest support for democratic values revealed by the same study.

In 2005-2006 there was another reform effort provoked by the dissatisfaction of various stakeholders. Parents, students, and teachers complained about overload on students, while experts and epistemic communities were concerned with lack of coherence and the detachment of teaching from "real-life." This criticism was targeted to CCE as well. However, most agree that the reform attempt did not bring about meaningful improvement. In the draft law, social studies subjects were rather mechanically combined with psychology and health education; some themes were dropped without adequate reasons. Due to such shortcomings the bill was never adopted by the government.

Curriculum reform in 2011 tried to solve the problem of study overload in a different way-by making clearer distinction between the lower and upper secondary schools. The underlying argument was that at lower secondary level CCE must be closely related to real social problems and prepare young people to take the role of active citizens. The next curriculum revision in 2014 strengthened this practical dimension further by replacing rather vague general social competences with social and citizenship competences. Descriptions of citizenship competences followed EU policy documents closely, such as European key competences in education and training. The nation state centric approach that had been dominant previously became less prominent while universal democratic and European values gained more visibility. Influenced by ICCS 2009, the subject name was changed from social studies to civic and citizenship education. Together with history and personal, social, and health education, CCE forms the subject field social studies in the national curriculum for lower secondary school, grades 6-9 (National curriculum 2011, Annex 5, 2014).

\section{Textbook Policy and Digital Turn in Teaching Materials}

In Estonia, national curriculum must be accompanied by teaching materials such as textbooks and workbooks. Therefore, every round of curriculum amendment is followed by the production of new textbooks or revision of existing textbooks. Textbook production is entirely within private for-profit companies who contract interested authors. As a result, there can be several textbooks for one particular subject simultaneously available, and schools choose among them. However, purchase of only those textbooks approved by the Ministry as conforming to the national curriculum is subsidized. This regulation gives both publishing houses and schools an interest in having textbooks that correspond to the national curriculum. 
Beyond printed textbooks and workbooks, digital learning materials, such as e-textbooks, interactive exercises, open educational resources, teachers' guides, and web-based assessment tools are becoming widespread. This development is part of the Estonian Lifelong Learning Strategy 2020, which has the "Digital turn" as one of the five directions (Ministry of Education and Research 2010). In the process of implementing the Lifelong Learning Strategy, the Ministry of Education requested compilation of digital learning resources, which were made publicly available online (see e-koolikott.ee). This activity was financed by the European Social Fund and gives every teacher free and easy access to modern teaching materials.

\section{National Exams and Change in Testing Policy}

In parallel to establishing the values and subject content of national curriculum an increasing emphasis on measuring the effect of civic education emerged. This was partly because of the opportunity to learn from neighboring and successful Finnish education policy and partly because of critiques by the OECD. Peer reviews by the Finnish Board of Education and OECD criticized the vague description of key competencies in Estonian curriculum that did not allow efficient measurement of study outcomes. As a by-product of these debates, Estonia decided to introduce national matriculation exams to measure learning outcomes defined in the National Curriculum. Once again, Finland served as a model (Toots 2009). The tasks and questions of the final examinations of the basic school are prepared by National Foundation, Innove; examination papers are graded by the final examination committees of schools, whose memberships are confirmed by the Minister of Education and Research. Although the exam on civic education is optional, i.e., it is up to the individual student whether to choose it, it has become one of the most popular exams. In 2016, 1339 students chose it compared to the 357 examinees choosing history, in 2018 the same figures were even more skewed towards CCE being 1819 to 304 respectively (Innove 2018).

The national policy of external testing has been rather volatile in the 2000s. Initial strong commitment to external accountability-oriented evaluation is being replaced by a stronger focus on internal self-evaluation of schools. In line with this change, an optional final exam in social studies at the end of upper secondary school has been abolished. Final exams on the lower secondary level still exist although their future has been debated. Volatility in approaches to quality assurance may be one of the reasons why researchers struggle with defining factors that explain the recent high performance of Estonian students in ICCS civic knowledge (Toots and Lauri 2015).

\section{Current Status and Characteristics of CCE in Curriculum}

National curriculum for the basic school, amended in 2014, defines learning outcomes at three levels: general competences, area competences in social studies, and subject-specific competences in civics and citizenship education.

At the general level, social and citizenship competence is described as the learner's "ability to become self-actualized, to act as an informed and responsible citizen supporting democratic development of society; to know and follow social values and norms, respect rules of various social environments and social, religious and ethnic diversity; to cooperate with other people in various situations; to accept and account for interpersonal differences" (Government of Estonia 2014). In the field of social studies, the aim of teaching and learning is "to develop in students age-appropriate social competences, namely ability to understand the causes and effects of changes in society; knowledge of and respect for human rights and democracy; knowledge of civil rights and responsibilities and ability to behave accordingly; ability to recognize cultural diversity; ability to follow generally accepted rules of conduct; interest in the development of community, nation, state and the world; ability to form personal opinions and be an active and responsible citizen; knowledge of and ability to use simple research methods in social studies; 
interest in the surrounding world" (Government of Estonia, 2014). In civics and citizenship education, by the end of their studies it is expected that students will "master social literacy: the knowledge, skills, values and attitudes necessary for fully acting in society and for making responsible decisions. The general aim of the subject is to create the preconditions for stronger cohesion between individual identity as a citizen and society" (ibid).

CCE is taught in grade 6, 35 hours per year and in grade 8 or 9,70 hours per year. Most schools locate CCE in grade 9, where students are 15 to 16-year-olds. Grade 9 is also the end of compulsory schooling.

\section{New Issues Incorporated into the Curriculum}

Modernization of the CCE curriculum has been influenced not only by domestic developments but also by initiatives of international organizations. The impact has been twofold: first, on the conceptual approach to civics and citizenship education and second, on topical content. The Council of Europe $(\mathrm{COE})$ has played an important role in advancing teaching of human rights and democratic citizenship. The CoE Reference Framework of Competences for Democratic Culture (2016) guided the 2019 revision of curriculum. Among learning outcomes, understanding multiculturalism and practicing intercultural dialogue are brought into focus. OECD's Learning Framework for 2030 serves as an important trend setter in national curriculum policy. In contrast to COE, OECD takes a broader approach in terms of topics and emphasizes the future of education and skills (OECD 2018). Within this future-oriented framework environmental issues (such as climate change) receive attention. Ecological concerns were reflected to some extent in teaching previously, but now the "think globally, act locally" approach is more prominent. Structurally, environmental issues are divided between science and citizenship studies; additionally, they are reflected among general competences.

Teaching about universal human rights and environmental issues did not meet resistance from politicians or educational policy stakeholders. However, such social consensus was not typical for all issues recently introduced into curriculum. Topics that have their roots in history (such as nation building, ethnic identities, world powers, World War 2) often cause controversies between majority and minority school communities, and more widely. For example, the political decision to include the Holocaust in the formal learning program was met with resistance from a significant portion of teachers and the public. Including Holocaust education in the school program was made conditional by NATO in 2003 to accepting Estonian membership in the alliance (Stevick 2011). Since then, Holocaust Day is remembered in Estonian schools. The International Holocaust Remembrance Alliance (IHRA), which Estonia has been a member of since 2007, provides materials to teach issues related to the Holocaust and antisemitism (Oja and Hiio 2007). Although today there is certainly more awareness about the topic, education on the Holocaust is not yet fully accepted as a responsibility of schools. The narrative of the Holocaust common in the West, which stressed individual responsibility and complicity of local actors in genocide, was perceived as incompatible with the Estonian national narrative which emphasized that Baltic nations were helpless victims of two totalitarian regimes (Stevick 2011).

\section{Specific Characteristics of Civic and Citizenship Education in Lower-secondary Schools}

Descriptions of compulsory subjects in Estonian national curriculum specify detailed educational objectives, subject's learning outcomes, and content for each major subject themes. Because IEA ICCS surveys 14-year-old students, the analysis below considers only this part of the curriculum, which is relevant to grades $8-9$.

There are four broad topics included in the CCE curriculum: economy, civil society, state and governance, and social relations. The latter includes also themes of media and information in contemporary society such as media freedom, rights and responsibilities in communication, 
cybersecurity, fake news, and skills for information mining and interpretation. Estonian governance is the most traditional topic and formerly meant learning of the national constitution. Today, this is complemented by topics on political parties, free elections, and voting behavior. Extension of these topics was triggered by politicians' plans to lower the voting age to 16 . The curriculum reform had broader aims and was not explicitly related to discussions of the voting age. However, learning outcomes concerned with electoral campaigns, media communication, and voting behavior were first included into CCE curriculum for lower secondary schools at this time. This marked a change from "pure" knowledge toward formally defined learning outcomes. An example was young people being able to "formulate a reasoned position as a voter" (Government of Estonia 2014).

Civil society themes are action-oriented because students can gain knowledge and skills for organizing citizen initiatives, volunteer activities, grass-root movements, and youth-oriented projects. Economic issues are approached with a double focus. On the one hand students acquire understanding of fundamentals of market economy, including the labor market, and on the other, they learn about everyday interactions with the economy and responsible consumerism. In sum, some attempts have been made to conceptualize citizenship cognitive competences as a unified system of knowing and reasoning (as in the ICCS framework). However, the dominant phrasing of learning outcomes in the curriculum is still that the student "describes," "explains," and "has understanding" (Government of Estonia 2014).

Although the latest curriculum revisions tackled the content overload problem, it had little success. There are still many unrelated topics, and the dominant focus remains on providing cognitive information. Teaching values and especially practicing those values in real citizenship activities is not widespread in schools. This can be explained by the Estonian political past and also by the pedagogical tradition of providing marks for students in all subjects, including CCE. Because grading of value perceptions and participatory activism is perceived as inappropriate, there is considerably greater emphasis on assessing students' cognitive competences.

This was the context for Estonia's participation in ICCS 2016. The study became an important point of reference for judging the revised curriculum of 2014. The target population of ICCS is 14-year-old students in grade 8; in Estonia these students have not yet taken the main course on CCE in grade 9. Nevertheless, Estonian students ranked fifth among 24 participating countries on the cognitive test of civic knowledge. Within a seven-year period (2009-2016) the average national score improved substantially (Schulz et al. 2018). This impressive progress demonstrates the country's efforts in transforming the national curriculum towards a broader society-centered concept of citizenship and successfully equipping students with knowledge and interpretative skills. Support for democratic values, attitudes towards civic engagement, and expected participation did not progress to a similar extent. While support for gender equality and rights of national minorities increased, on the ICCS citizenship scales Estonia continued scoring significantly below the study averages (Schulz et al. 2018). Readiness of Estonian adolescents to engage in some types of civil or political activity stagnated or even declined compared to previous study cycles (Toots 2017; Kõiv 2018).

\section{Teachers of Civics and Citizenship}

\section{Qualification Requirements for CCE Teachers in Lower-secondary Schools}

All teachers in Estonia need to have a higher education diploma; for subject teachers a master's degree is obligatory. Since 2013, Estonia has applied the European Qualification Framework for defining occupational qualifications for the teaching profession. However, until recently, the demand exceeded the supply of teachers, and it was not always possible to require high professional standards. Today, the problem is not the lack of teachers, but the difficulty in providing teachers with a full-time workload. The problem lies in declining and ageing populations in rural 
areas, resulting in small school sizes. In CCE the problem with workload is even more serious since there are few classes in the subject. CCE is typically taught by teachers of history, but other combinations are possible depending on the human resources available in each particular school. There are no subject-specific requirements to teach CCE.

\section{General and Specific Training of CCE Teachers in Lower-secondary Schools}

Teacher training in Estonia is provided by two public universities, University of Tartu and Tallinn University. These schools are responsible also for initial training in CCE. As there are limited possibilities to find a future job teaching CCE only, there is no dedicated teacher program in social studies. Instead, relevant competences can be gained through a minor in the study program of history teachers. Estonian universities enjoy substantial autonomy in designing study programs, and the structure and content of programs varies across higher education institutions. However, every study program in teacher training must comply with the National Framework of Teacher Training (2000) and is subject to a quality evaluation process. The framework stipulates that all future teachers must gain competences that allow them to understand plurality of opinions, to be tolerant, and to have democratic attitudes (Government of Estonia 2000). Secondary subject training (i.e., minor) must compose of at least 30 credits out of 200.

\section{Opportunities for Professional Development of CCE Teachers}

National policy concerning in-service training in Estonia is rather fragmented, and the Ministry of Education and Research plays a minor role. With the collapse of the Soviet regime, the former massive system of in-service training ceased to exist. In the 1990s several foreign donors were active in the field, such as Soros Foundation, some German foundations (Friedrich Naumann, Konrad Adenauer, Friedrich Ebert), and United States organizations (National Endowment for Democracy; Center for Civic Education). Some domestic actors (nongovernmental organizations, think-tanks, teacher unions) organized training seminars with invited speakers, including top level civil servants and policy experts. However, these seminars were organized as single events with project-based funding. Grant rules affected the number of participants and themes of training. For example, after Estonia became a member of the EU, funds from that organization were allocated to organize in-service teacher training on EU matters. A brief distance-learning course on the EU, financed by the EU Commission Representation in Estonia had 179 teachers participating in 2004, but a year later just 19. In the following years the participation numbers went up but did not reach initial levels (Tallinn University 2013).

Overall, EU guidelines and financial support implemented through domestic government agencies have become important in encouraging teacher training. However, this has not resulted in a stable in-service training system. Autonomous universities are not interested to become involved, nor does the Ministry of Education and its agencies have that capacity. This has resulted in fragmentation and poor coordination of professional development. Half of school headmasters claim that absence of one comprehensive database describing training courses is a major obstacle in efficient planning of in-service teacher training (Balti Uuringute Instituut [BUI] 2015). According to existing regulations, a teacher must take 160 hours of training within five years. This system is criticized by many parties including teachers themselves because this focus on hours of training does not meet actual needs for professional development (Roon 2014). 


\section{Presence of Civic and Citizenship Education in Education Discourses and their Influence}

\section{Influence of CIVED/ICCS on Curriculum Development and Textbooks}

The first IEA study in CCE where Estonia participated (CIVED) had the biggest effect on curriculum. In these years Estonia was still in the process of transforming formal teaching from a totalitarian Soviet style to democratic civic education. Therefore, domestic expertise was scarce and the willingness to incorporate foreign practices high. The content of the CIVED survey instruments served as a solid argument to expand the content of curriculum from government studies to social issues and democratic values. Yet, education about democratic values did not find broad support in the educational community, and traditional provision of cognitive competence in civic-related topics has remained central. Within this context, the poor performance of Estonian students in CIVED was used as evidence for introducing external evaluation of schools in civic education in 2001/2002. In 2005/2006 an external test was replaced by the final exam at the end of lower secondary education. Compared to the learning outcomes in the national curriculum, this exam had stronger emphasis on assessing argumentation and critical thinking skills.

In the course of curriculum development, it has been recognized that teaching needs to become more age-relevant and closer to the everyday life experiences of young people. ICCS played an important role in extending the scope of the subject beyond the national boundaries and putting greater emphasis on the age-relevance of topics and learning outcomes. The task force that drafted the national curriculum 2011 consulted the ICCS 2009 assessment framework and survey instruments when selecting the topics to be included.

Close links between the curriculum and teaching materials facilitated use of ICCS findings in civic textbooks for grades 8-9. The survey statistics of Estonian respondents on attitudes towards gender equality and minority rights, trust towards institutions, and perception of characteristics of democracy, was used to compose study tasks for advancing data literacy and interpretation skills. The first time ICCS findings were presented was in the textbook of 2003 (CIVED data), then in 2007 and 2014 (ICCS 2009), and 2018 (ICCS 2016). This link between IEA studies and national textbooks has been facilitated by the fact that the Estonian national research coordinator for all CIVED/ICCS study cycles, Anu Toots, was also the author of civic textbooks.

\section{Influences of the Studies on Identity Politics and Citizenship Policy}

As mentioned in the introduction, Estonia inherited from the Soviet period a large Russianspeaking population that has had enormous effect on social processes and policies. CIVED/ ICCS made positive contributions in tackling two policy-related issues: national citizenship and the bilingual education system.

When Estonia restored its independence as a sovereign republic in 1991, the citizenship regulations of the previous Republic (1920-1940) were also reinforced. As a result, large numbers of Soviet immigrants and their children were left without Estonian citizenship. Because of broader political turbulence caused by the Soviet Union's breakdown, the share of stateless persons in Estonia was as high as 23\% in 1998 and the share of Estonian citizens only 65\% of the total population (Ministry of Interior 1998). In order to obtain Estonian citizenship other than by birth, a person has to take an exam on Estonian language and on the national constitution. To facilitate the process, it was decided to combine the final exam on civic education with the Estonian citizenship exam. Those students in Russian speaking schools, who wanted to apply for citizenship, could answer an additional module on topics stipulated in the Citizenship Act. Extra time was afforded and it was assessed separately from the final exam scores. If the module was passed, then it counted for the state exam on the Constitution and Citizenship Act (Government of Estonia 2008). 
This possibility to obtain Estonian citizenship through formal CCE drew the attention of education policymakers to the quality of CCE in schools with Russian as the language of instruction. Comparison of study results across the years show that important differences in attitudes and engagement patterns between Estonian and Russian speaking students have remained, and the achievement gap has even widened (Toots and Idnurm 2012; Toots 2017). Several national surveys (Vihalemm and Leppik 2017; Toomela and Kikas 2012) confirmed findings of IEA civic and citizenship studies on variation in democratic attitudes, behavioral patterns, and school climate between the language groups. Relevant CIVED and ICCS 2009 and 2016 findings were also mentioned in Estonian Human Development Reports (Toots 2008; Toots and Lauri 2013) and National Youth Monitor (Toots and Idnurm 2018). These efforts have informed policymakers outside the field of education about the challenges of minority schools and have also contextualized CCE issues within a broader set of problems. The dominant concern so far has been the transition of upper secondary schools to using the state language and improving the quality of state language teaching in lower secondary schools. As a consequence of revised national integration policy in 2008 and IEA study results, the questions of democratic attitudes and civic engagement gained more prominence. The Integration Monitor (Ministry of Culture 2011) made policy recommendations that state-centric subject of social studies should be transformed into value-centric citizenship education that would allow cultural "translation" of the meaning of democratic citizenship. The agreement between the Ministry of Education and Research and Tallinn University on implementing ICCS 2016 specifically requested separating findings for Estonian-speaking and Russian-speaking schools. So, at policymaking level the problems of CCE quality in minority schools are reflected, but no practical measures, such as special teacher training or learning materials. is taken. There are several reasons. First, CCE as an educational area does not have a high profile in current domestic debates generally. Second, Russian-speaking students are not anti-democratic in their attitudes and therefore the problem was not perceived as urgent. Third, Estonia still lacks a nationally coordinated in-service training system. Compared to teachers in Estonian-speaking schools, teachers in Russian-speaking schools are less satisfied with the availability of professional training courses (BUI 2015). They could take part in courses provided by Western agencies but poor knowledge of English and of Estonian is a barrier for many Russian-speaking teachers. Some training courses specifically designed for Russian-speaking teachers of civic education, were organized by the nongovernmental organization Jaan Tõnisson Institute and by the Association of History and Civic Teachers, but these occasional events could not fundamentally improve the existing fragmented system (Oja 2014).

\section{Role of ICCS Results in Enhancing Youth Civic and Political Participation}

Beyond educational and youth policymakers and practitioners, interest in ICCS results has been developed in the Ministry of Interior and Ministry of Justice. They have been interested primarily in democratic attitudes, and civic and political participation of adolescents. This contrasts with education policy actors whose main concern remains civic knowledge.

The most fundamental initiative where ICCS 2009 results provided evidence for policy change was lowering of the voting age to 16 in 2015. The strategic aim of lowering the voting age at municipal elections was to engage young people more actively in debating and deciding on local public affairs (Riigikogu 2014). Voting age is stipulated by the Estonian Constitution, which implies lengthy legal amendment procedures. Better preparations for parliamentary voting were also necessary. The broader public and some bigger political parties in parliament were skeptical about the idea. The dominant opinion was that young people are "not ready" and do not understand politics. In this situation, Ministry of Justice commenced analyses on practices of foreign countries on lowering the voting and an ex ante impact assessment of possible change in Estonia. The impact assessment was commissioned from the researchers of Tallinn University, who had been responsible for carrying out CIVED and ICCS 2009 in Estonia. 
Findings of ICCS 2009 were extensively used in analyzing the possible effects of lowering the voting age. Moreover, comparison of national results with the ICCS 2009 findings of Austria, which lowered the voting age for all elections in 2005, demonstrated the feasibility of similar change in Estonia (Toots et al. 2014). First results of the impact assessment were announced at an open session of the Constitutional committee of the parliament, which was a trigger for parliamentary activities-four weeks later (July 2014) the bill to amend the Constitution was initiated and passed in May 2015.

Positive national findings of ICCS 2009 and an impact assessment report contributed significantly to countering the arguments against the lower voting age. As a result, parliamentary debates were transformed into discussions on the quality of CCE. During the period of parliamentary proceedings (2012-2015) problems and challenges of civic and citizenship education have been debated three times in open sessions of the Constitutional committee and Committee of Cultural Affairs. Various stakeholder organizations such as the Association of History and Civic Education Teachers, Association of Student Unions, Network of Estonian Nonprofit Organizations, Estonian Scout Association, and Youth Parliament of Narva City participated. However, the discussions ended without any real impact on education policy, such as amendment of national curriculum or revision of teacher training. The debate focused mainly on extracurricular activities and electoral campaign regulations in schools (Toots and Idnurm 2020).

Differing from intensive debates among politicians and some youth representatives, young people in general remained passive observers of the process. Adolescents' perceptions toward voting as a characteristic of a good citizen, and their personal voting intentions in adulthood remained unchanged in ICCS 2016 compared to 2009. By time of the 2016 survey Estonia had already lowered the voting age at municipal elections to 16 , which suggests that legal amendment did not immediately affect attitudes of 14-year-olds towards electoral behavior.

\section{Areas with Little Influence}

Despite expectations, several important areas were affected very little by the IEA CCE studies. This is true for teacher training and broader public interest towards citizenship education in the mass media. The problem with teacher training is twofold. The existing fragmented training system without clear institutional responsibility does not support strategic development of training courses on the one hand. On the other, Estonian teacher training does not have a tradition of quantitative, measurement-oriented approaches. The problem with the low public interest may be interpreted via a famous saying by William K. McElvaney (1980), "good news is bad news is good news." In CIVED, Estonian students scored in the bottom quartile among the 28 participating countries in civic knowledge, in most democratic attitudes the national scores were below international average. These results caused several newspaper articles to voice concerns about the existing level of CCE. In ICCS Estonia performed much better in civic knowledge, whilst staying at average in democratic attitudes and behaviors; there was nothing extraordinary that could catch the eye of journalists.

Ironically, the impressive progress that Estonia has made in the 25 years since the collapse of the totalitarian Soviet system has been associated with a decline in interest about international large-scale assessment results. This argument holds not only for the IEA ICCS, but also for the OECD PISA. Two explanations can be suggested. Firstly, in the end of the 1990s the re-established democratic republic was eager to integrate to the West. All possibilities to compare Estonia with Western countries were seen as benchmarks and milestones in this process. The willingness to learn from the West was widespread among policymakers and educational practitioners as well (Toots 2009). Today, there is much more confidence in domestic capacities to design and implement education policies including setting national strategic goals and indicators. This has changed the focus of comparison. When in previous periods, the main interest was towards 
cross-country comparison, now the comparison of schools within the country is the focus. Since IEA studies cannot be directly used for such purposes, a considerable number of national surveys has emerged on topics such as school climate and governance, students' satisfaction, and participatory attitudes. Secondly, at the time of CIVED the impact of international organizations such as OECD, or supranational actors such as the EU, was much smaller. Today, Estonia is a full member of OECD and the EU, and has to follow their policies and benchmarks. It also means obligation to participate in OECD PISA. In this situation, IEA needs to make well-founded efforts to persuade policy executives on the added value of TIMSS, PIRLS, ICILS, ${ }^{1}$ and ICCS. It is worth noting that the EU Commission's support of ICCS 2016 and 2022 played a crucial role in the decision of the Ministry of Education and Research to participate in the studies.

\section{Summary and Conclusions}

Estonia has participated in all three IEA CCE studies since 1999. The fact that this is the only IEA study in which the country is participating (besides TIMSS 2003 and SITES 2006²) can be interpreted as evidence of the importance and quality of ICCS. Broadly speaking, two areas of impact of IEA's CCE studies can be highlighted: curriculum development and political participation of youth.

In the early 2000s when the country was transforming education from a totalitarian to a democratic system, the CIVED analytical framework and study findings played an important role in developing the democratic curriculum of citizenship education. However, the CIVED approach was mediated through the national pedagogical traditions. Notwithstanding the political regime change, providing students with civic knowledge was regarded as the most important mission of school. Therefore, CIVED civic knowledge rankings received the main attention of policymakers. As a result of the poor performance of Estonian students, a final exam for lower secondary school in civic education was introduced in 2005/2006 in order to increase the status of the subject and improve the achievement levels.

The next IEA study cycles in 2009 and 2016 contributed to curriculum reform by giving more legitimacy to the efforts to teach democratic values and citizenship skills. However, these efforts did not result in sound and widespread change in teaching practice, which remains in most schools a conventional textbook based activity. "I think, our citizenship education should be even more practical," the Minister of Education and Research said at the meeting of the Committee of Cultural Affairs of National Parliament (Reps 2018). This attention may create a momentum for improvement.

Practical, real-life skills of living democracy were tested with the amendment of the Estonian Constitution in 2015 lowering the voting age at municipal elections to 16 . In preparing the parliamentary decision, ICCS 2009 findings were of crucial importance. Good performance of Estonian students and comparison with Austria, which also has the voting age at 16, helped to fight the argument that young people are not mature enough to make autonomous voting decisions.

Besides this particular case of lowering the voting age, ICCS 2009 and 2016 findings on youth participatory attitudes and civic engagement inside and outside school have been used in several policy reports to inform both young people and policymakers about the current situation and trends. Large volumes of policy analyses and reports that make use of international or domestic studies are an important feature of current evidence-based policymaking. However, an investigation by the National Audit Office revealed that there are several shortcomings in using studies commissioned by the state (National Audit Office 2015). In the majority of cases the purpose of studies is to obtain overviews of problems or sectors, and much more rarely

1 TIMSS = Trends in International Mathematics and Science Study; PIRLS = Progress in International Reading Literacy Study; ICILS = International Computer and Information Literacy Study.

2 SITES = Second Information Technology in Education Study. 
are studies used for decision-making. Furthermore, due to shortcomings in inter-ministerial communication, it is difficult to find out what studies different agencies are planning to commission in the near future, which may lead to underuse of results and even duplication of studies. This criticism is relevant generally to education policy, CCE included. Typically, studies are carried out by universities or state agencies. This may leave the ministry, who is the key policy designer, outside the information flows. As the National Audit Office report states, it is paramount to maintain good communication between the institution who commissioned the study and the actual performer of it (National Audit Office 2015). The more vital this link is the more efficient is the later use of study results. However, this kind of communication works best in stable institutional environments, especially in case of multi-cycle studies such as IEA's ICCS. In the process of organizational changes, know-how and study "memory" can be easily lost. In the case of fragmented and decentralized systems the use of study findings depends largely on bottomup activity of end users. For example, recent Estonian experience suggests that relatively new nongovernmental organizations acting in the field of environmental and global issues are more enthusiastic about learning from ICCS results than are conventional teacher training institutions.

\section{References}

Amadeo, J., Torney-Purta, J., Lehmann, R., Husfeldt, V., \& Nikolova, R. (2002). Civic knowledge and engagement: An IEA study of upper secondary students in sixteen countries. Amsterdam, the Netherlands: International Association for the Evaluation of Educational Achievement (IEA).

Balti Uuringute Instituut [BUI]. (2015). Uuringu 'Õpetajate täiendusõppe vajadused' Iõpparuanne [Final report on demands of teachers' in-service training]. Tartu, Estonia: Balti Uuringute Instituut. https://dspace. ut.ee/bitstream/handle/10062/45196/Opetaja_taiendoppe\%20vajadus.pdf?sequence=1\&isAllowed=y Council of Europe. (2016). Competences for democratic culture. Living together as equals. Strasbourg, France: Council of Europe Publishers.

Government of Estonia. (2014). National curriculum for basic schools 2011. https://www.riigiteataja.ee/ en/eli/ee/VV/reg/524092014014/consolide

Government of Estonia. (2008). Kodakondsuse taotleja Eesti Vabariigi põhiseaduse ja „Kodakondsuse seaduse" tundmise eksami läbiviimise kord. [Procedure on implementation of government regulation No 143 on organization of exams on Constitution of Estonian Republic and Citizenship Act]. RT I, 2013, 4. https://www.riigiteataja.ee/akt/119072013007

Government of Estonia. (2000). Õpetajate koolituse raamnõuded [National framework for teacher training]. RTI, 87, 575. https://www.riigiteataja.ee/akt/812791

Innove. (2018). Statistics on basic school final examinations. Tallinn, Estonia: SA Innove. https://www. innove.ee/eksamid-ja-testid/pohikooli-lopueksamid/lopueksamite-statistika/

Krzywosz-Rynkiewicz, B., Zalewska, A., \& Kennedy, J.K. (Eds.). (2018). Young people and active citizenship in post-Soviet times: A challenge for citizenship education. London, United Kingdom: Routledge.

Kõiv, K. (2018). Estonia: citizenship behaviour among today's youth. In B. Krzywosz-Rynkiewicz, A. Zalewska, \& J.K. Kennedy (Eds.), Young people and active citizenship in post-Soviet times: A challenge for citizenship education (pp. 80-96). London, United Kingdom: Routledge.

Macek, J., Macková, A., Pavlopoulos, V., Kalmus,V., Elavsky, C.M., \& Šerek, J. (2018). Trust in alternative and professional media: The case of the youth news audiences in three European countries. European Journal of Developmental Psychology, 15(3), 340-354. https://doi.org/10.1080/17405629.2017.1398079

Ministry of Culture. (2011). Integratsiooni Monitooring 2011 [Integration Monitor 2011]. Tallinn, Estonia: Kultuuriministeerium, TNS Emor, Praxis, Tartu Ülikool. https://www.kul.ee/sites/kulminn/files/ integratsiooni_monitooring_2011.pdf

Ministry of Education and Research. (2010). The Estonian lifelong learning strategy 2020. https://www. hm.ee/sites/default/files/estonian_lifelong_strategy.pdf

Ministry of Interior. (1998). Kodakondsuse statistika [Statistics on citizenship status]. Tallinn, Estonia: Siseministeerium.

Motti-Stefanidi, F., \& Cicognani, E. (2018). Bringing the European Union closer to its young citizens: Youth active citizenship in Europe and trust in EU institutions. European Journal of Developmental Psychology, 15(3), 243-249. https://doi.org/10.1080/17405629.2017.1423052 
National Audit Office. (2015). Activities of the state in commissioning studies. Report of the NAO to the Riigikogu. Tallinn, Estonia: Riigikontroll [National Audit Office]. https://www.riigikontroll.ee/tabid/206/ Audit/2345/language/et-EE/Default.aspx

Oja, M. (2014). Ühiskonnaõpetuse õpetajate koolitused. Kakskümmend aastat Eesti Ajaloo- ja Ühiskonnaõpetajate Seltsi [Training of civic education teachers. Twenty years of Estonian History and Civic Education Teachers' Association]. Tallinn, Estonia: Eesti Ajalooõpetajate Selts.

Oja, M., \& Hiio, T. (Eds.). (2007). Holokaust. Õppematerjal [Holocaust. Teaching materials]. Tallinn, Estonia: Eesti Ajalooõpetajate Selts. https://www.humanrightsestonia.ee/wp/wp-content/uploads/2013/05/ holokaust-30.12.pdf

Organisation for Economic Co-operation and Development (OECD). (2018). The future of education and skills. E2030 position paper. Paris, France: OECD Publishing. http://www.oecd.org/education/2030/ E2030\%20Position\%20Paper\%20(05.04.2018).pdf

Pilkington, H., \& Pollock G. (2015). 'Politics are bollocks': youth, politics and activism in contemporary Europe. The Sociological Review, 63(S2), 1-35. https://doi.org/10.1111/1467-954X.12260

Reps, M. (2018). Ajaloo- ja ühiskonnaõpetus kui ühendaja ja indetiteedi looja [History and citizenship studies as identity builders]. Õpetajate Leht, No. 11, 23. March. https://dea.digar.ee/cgi-bin/dea?a=d\&d= opetajateleht20180323.2.5.3

Riigikogu. (2014). Seletuskiri Eesti Vabariigi põhisaduse muutmise seaduse ja kohaliku omavalitsuse volikogu valimistel valimisea langetamiseks eelnõu 703SE juurde [Explanatory memorandum to the bill on amendment of the constitution of Estonian Republic and lowering the voting age at municipality councils' election]. Tallinn, Estonia: Riigikogu. https://www.riigikogu.ee/tegevus/eelnoud/eelnou/bOf58e59-bf3640e3-bbd7-3aff08428bdf/Eesti\%20Vabariigi\%20p\%C3\%B5hiseaduse\%20muutmise\%20seadus\%20 kohaliku\%20omavalitsuse\%20volikogu\%20valimistel\%20valimisea\%20langetamiseks

Roon, M. (2014). Ministeerium: õpetajate täiendkoolitused ei täida oma eesmärki [Ministry: Teachers inservice training does not fulfill its objectives]. Tallinn, Estonia: Estonian National Broadcast. https://www. err.ee/492612/ministeerium-opetajate-taiendkoolitused-ei-taida-oma-eesmarki.

Schulz, W., Ainley, J., Fraillon, J., Kerr, D., \& Losito, B. (2010). ICCS 2009 international report: Civic knowledge, attitudes and engagement among lower secondary school students in thirty-eight countries. Amsterdam, the Netherlands: International Association for the Evaluation of Educational Achievement (IEA).

Schulz, W., Ainley, J., Fraillon, Losito, B., Agrusti, G., \& Friedman, T. (2018). Becoming citizens in a changing world. IEA International Civic and Citizenship Education Study 2016 international report. Cham, Switzerland: Springer. https://doi.org/10.1007/978-3-319-73963-2

Statistics Estonia. (2020). General education schools by type of school and county. http://andmebaas. stat.ee/Index.aspx?lang=en\&SubSessionld=18a4fa6a-4174-4902-885e-951e446829a0\&themetreeid=6

Stevick, E. D. (2011). Finessing foreign pressure in education through deliberate policy failure: Soviet legacy, policy prescriptions, and democratic accountability in Estonia. In J.N. Hawkins, \& W.J. Jacob (Eds.), Policy debates in comparative, international, and development education (pp. 175-198). New York, NY: Palgrave. Tallinn University. (2013). Tallinna ülikooli täiendõppekeskuse direktori käskkirjad ja korraldused 2001 2013 [Directives and orders of the director of the Tallinn University Continuing Education Center 2001-2013]. Tallinn University. Vol 8.2-2, pp. 13-25.

Toomela, A., \& Kikas, E. (Eds.). (2012). Children studying in a wrong language: Russian-speaking children in Estonian school: Twenty years after the collapse of the Soviet Union. Frankfurt, Germany: Peter Lang.

Toots, A. (2008). School democracy in Estonia. In M. Heidmets, (Ed.), Estonian Human Development Report 2007 (pp. 39-45). Tallinn, Estonia: Eesti Koostöö Kogu.

Toots, A. (2009). Brussels comes via Helsinki: The role of Finland in europeanisation of Estonian education policy. Halduskultuur, 10, 58-73.

Toots, A., \& Idnurm, T. (2012). Does the context matter? Attitudes towards cosmopolitanism among Russian-speaking students in Estonia, Latvia and the Russian Federation. Journal of Baltic Studies, 43(1), 117-34

Toots, A., \& Lauri, T. (2013). Education. In Estonian Human Development Report 2012/2013. Estonia in the World (pp. 30-40). Tallinn, Estonia: Eesti Koostöö Kogu.

Toots, A., Idnurm, T., \& Saarts, T. (2014). Aktiivse valimisea langetamise mõjude analüüs: eelhindamine [Lowering the voting age: Ex ante impact assessment]. Tallinn, Estonia: Tallinn University. 
Toots, A., \& Lauri, T. (2015). Institutional and contextual factors of quality in civic and citizenship education: Exploring possibilities of qualitative comparative analysis. Comparative Education, 51(2), 247-275. https: //doi.org/10.1080/03050068.2014.985926.

Toots, A. (Ed.). (2017). Noorte kodanikukultuur muutuvas maailmas. Eesti tulemused IEA Rahvusvahelises Kodanikuhariduse Uuringus (ICCS 2016) [Youth civic culture in changing world: Estonina findings in IEA International Civic and Citizenship Education Study ICCS 2016]. Tallinn, Estonia: Tallinn University, Ministry of Education and Research.

Toots, A., \& Idnurm, T. (2018). Kodanikuosaluse mustrid eesti ja vene õppekeelega koolides [Patterns of citizenship engagement in Estonian and Russian speaking schools]. In Noorteseire aastaraamat 2017-2018. Noored ja osalus [Youth monitor 2017-2018: Youth and participation] (pp. 65-90). Tartu, Estonia: Eesti Noorsootöö Keskus.

Toots, A., \& Idnurm, T. (2020). Modernizing voting in a post-transition country: Estonian experience in lowering the voting age. In J. Berg, \& J. Eichhorn (Eds.), Lowering the voting age to 16: Learning from real experiences worldwide. Palgrave Studies in Young People and Politics Series. London, United Kingdom: Palgrave Macmillan.

Torney-Purta, J., Lehmann, R., Oswald, H., \& Schulz, W. (2001). Citizenship and education in twenty-eight countries: Civic knowledge and engagement at age fourteen. Amsterdam, the Netherlands: International Association for the Evaluation of Educational Achievement (IEA). https://www.iea.nl/publications/studyreports/international-reports-iea-studies/citizenship-and-education-twenty-eight

Vihalemm, T., \& Leppik, M. (2017). Eestivenekeelse elanikkonna lõimumise viisid ja muutustega kohanemise praktikad [The patterns of involvement and adaptation with social changes among Estonian Russian-speaking population]. In P. Vihalemm, M. Lauristin, V. Kalmus, \& T. Vihalemm (Eds.), Eesti ühiskond kiirenevas ajas. Uuringu Mina. Maailm. Meedia 2002-2014 tulemused (pp. 557-591). Tartu, Estonia: Tartu University Press.

Open Access This chapter is licensed under the terms of the Creative Commons Attribution-NonCommercial 4.0 International License (http://creativecommons.org/licenses/by-nc/4.0/), which permits any noncommercial use, sharing, adaptation, distribution and reproduction in any medium or format, as long as you give appropriate credit to the original author(s) and the source, provide a link to the Creative Commons license and indicate if changes were made.

The images or other third party material in this chapter are included in the chapter's Creative Commons license, unless indicated otherwise in a credit line to the material. If material is not included in the chapter's Creative Commons license and your intended use is not permitted by statutory regulation or exceeds the permitted use, you will need to obtain permission directly from the copyright holder. 